\title{
NARRATIVE PRODUCTION WEAKNESS IN RUSSIAN DYSLEXICS: LINGUISTIC OR PROCEDURAL LIMITATIONS?
}

\author{
Aleksandr N. Kornev, Ingrida Balčiūnienè
}

\begin{abstract}
The study deals with the impact of non-linguistic factors on narrative production in Russian-speaking dyslexic children. The experimental group consisted of 12 children (age 9-10) with dyslexia and the control group comprised 12 peers without any developmental disorders. The sample was counterbalanced from the perspective of narrative mode, story complexity, and task order. One of the classic methodologies for narrative analysis, i.e. story grammar, was extended in our study by a novel dynamic approach, enabling us to evaluate procedural features of narrative production.

The results of our study highlight limitations in dyslexic narrative language underlined by two different causes. The first one can be defined as inefficiency in developing logical (temporal/causal) relationships between events; the other is difficulties in structuring an episode description. The high flexibility and dynamic changes in the episode structure in dyslexics anticipated the evidence that limitations in dyslexic narrative language are related to the deficit in procedural functions rather than to the primary language limitations; however, linguistic shortcomings in dyslexic narrative production still remain.

Our experience with the dynamic approach to narrative assessment lends support to its value as a research tool. The novel dynamic approach to episode completeness analysis proved to be an effective and informative method that might highlight new mechanisms of narration and thus extend the classic narrative analysis by the addition of qualitative information.*
\end{abstract}

Keywords: first language acquisition, language pathology, Russian 


\section{Introduction}

It is well known that for some children learning to read proceeds very slowly and inefficiently (Pressley 2006). The struggling readers are usually classified into those with specific and nonspecific reading disabilities (Snowling 1996, Voeller 2004). The prevalence of specific reading disabilities or developmental dyslexia among a population reaches $11 \%$ in languages with shallow literacy and as much as $3-5 \%$ in languages with transparent literacy (Lindgren et al. 1985, Shaywitz, Shaywitz 2003). In Russia, about $5 \%$ of school-age children are dyslexics (Kornev 1995, Kornev, Išimova 2010). Generally, dyslexia can be defined as a selective disability to learn reading in spite of regular education and normal intelligence (Lyon et al. 2003). From the perspective of the Russian-speaking population, the following difficulties are usually recognized: a) immature recoding and decoding skills, indicating that the child has difficulty in transitioning from letter- to syllable- to word reading; b) low reading fluency; c) lack of accuracy while reading aloud; e) sometimes a lack of comprehension, both at the word and sentence levels (Kornev et al. 2010).

Skills in reading and text comprehension are highly correlated with those in narrative production and comprehension. However, the direction of the correlation is still not clear. Does experience in reading affect the quality of narrative production? Or - vice versa - are skills in discourse necessary prerequisites for reading development? Following modern theoretical models, reading is considered an active and creative process of so called 'text image generation' (van Dijk, Kintsch 1983, Kintsch 1988, Leontyev 1997, 2004) that includes a) (re-)encoding (also called 'decoding'), and b) elaboration of connection (coherence) between words and relating of word units in a logically coherent structure, i.e. text base (Gorin, Embretson 2006). According to Walter Kintsch and Teun A.van Dijk (1978), text processing can be interpreted as an iteration of the construction and integration processes. A text, as a set of propositions, is continuously integrated through the reader's experience. According to the later theoretical model (Kintsch 1988, 1998), text comprehension can be interpreted as a cyclical process. During one cycle, a reader extracts propositions from the text and binds them into a logically coherent network. In the integration phase, the network is activated with the maximum activity level at the points of the highest correlations. After each of the cycles, the most activated propositions are transferred from the working memory to the next cycle for the further process of analysis and synthesis.

General reading ability is related to tacit knowledge of the structural importance of story units (Smiley et al. 1977), and knowledge about stories may also influence reading performance. For example, Charles A. Perfetti (1994) has proposed that a possible source of comprehension failure is inadequate reading experience; Carole Peterson and Pamela Dodsworth (1991) have noted that narrative production is used in school to develop children's reading and writing skills. In a number of studies in narrative production, components similar to those involved in the text comprehension have been mentioned (e.g. Cain 2003, Mar 2004).

In this respect it should be reasonable to use narrative analysis as a tool to identify the mechanisms underlying text processes in reading in both the normal and language-impaired population. 
During the last few decades, narrative analysis has been applied as a language assessment and/or intervention tool in many different fields, including but not limited to developmental psycholinguistics, psychology, linguistics, speech therapy, and education. The methodology of narrative analysis is considered ecologically valid and flexible, and thus applicable for different linguistic, cultural, and social populations. The great variety of methodological approaches to narrative analysis (The Cat Story, The Horse Story (Hickmann 2003), different versions of The Frog Story (e.g., Mayer 1967), The Bus Story (Renfrew 1969), TNL (Gillam, Pearson 2004), The Stone Story (Veneziano, Hudelot 2009), ENNI (Schneider et al. 2005), MAIN (Gagarina et al. 2012)) naturally leads to debates on the pros and cons of different methods and tools. After many years of discussions, personal narratives are considered to be informative when comparing different cultures and linguistic communities (McCabe, Bliss 2003) and also to serve as a clinical tool (Bliss et al. 1998, Bliss, McCabe 2008), while fiction stories (both telling and retelling) might be easily applicable for child language studies. However, a variety of different approaches to fiction narratives (e.g., task mode such as telling, retelling, or model story; visual stimuli such as picture, picture sequence, or video; shared vs. non-shared attention) not only enables but also encourages to search for the most relevant assessment tool for a particular linguistic, cultural, and social population. A number of studies have been based on comparative analysis between different presentations of stimuli in both typicallydeveloping (TD) and language-impaired (LI) populations (Schneider 1996, Botting 2002, Schneider, Dubé 2005, Soodla et al. 2010, Soodla 2011); however, it must be noted that the majority of the studies focused on only linguistic measures such as macro- and microstructural characteristics, while the impact of cognitive factors (e.g. the subject's working memory, serial ordering, attention) still seems to be ignored (but see Mar 2004). The traditional static approach focuses on the result of narration, but the process-based approach (also called 'dynamic assessment') might significantly extend narrative analysis (Gillam et al. 1999).

There is an urgent need for complex methodology that combines linguistic and cognitive approaches and thus enables an analysis of both the process and the result of narration in the context of studies in language impairments. Languageimpaired children, despite pure linguistic limitations, demonstrate emotional disorders (Kornev 2006), impaired executive function (Im-Bolter et al. 2006), limitations in visuo-spatial processing (Marton 2008), ADHD (Bellani et al. 2011), and low self-esteem (McAndrew 1999), thus the impact of non-linguistic factors on narrative comprehension/production should be particularly taken into account when assessing language-impaired populations.

There are relatively few studies devoted to cognitive experimental evaluation of the discourse (including narrative) process in both production and comprehension (Mar 2004). A story is, in part, a coherent causal-temporal ordering of selected information. It can be argued that a person must possess an ability to distinguish between story-significant and story-insignificant elements in order to construct a story. The capacity to properly sequence these events with regard to time and influence appears to be of fundamental importance for this process. Story grammar knowledge has been associated with the super-structural level of discourse organization, involving the integration of conceptual semantic and pragmatic information. This level of discourse processing is thought to be reliant on executive 
functions (e.g., working memory, sequencing, and planning); see Coelho (2002), Tucker and Hanlon (1998). Experiments have provided evidence suggesting "that when evaluating narrative discourse ability, the integration of organizational and content measures yields an index of story goodness that was found to be sensitive and reliable in discriminating individuals with no brain injury and individuals with brain injury" (Lê et al. 2011: 124). The same seems reasonable for distinction between developmentally disordered individuals.

Results of our previous studies (Kornev, Balčiūnienè 2014) have confirmed that narrative macro- and microstructure are influenced by non-linguistic procedural variables such as cognitive resources that include working memory, serial ordering, etc. According to the competing model of speech processing in utterance programming, different components compete with each other for the cognitive resources necessary for parallel execution (MacWhinney, Bates 1989).

In our study, we attempted to evaluate the impact of non-linguistic factors such as task mode (telling vs. retelling), story complexity (relatively easy vs. complex story), and session (task order) on the comprehension and production of narrative macrostructure in dyslexic children. While comparing experimental and control groups, we expected to find the most sensitive linguistic measures that are directly dependent on non-linguistic factors and the conditions of narrative assessment in dyslexic children.

\section{Methodology}

\subsection{Subjects}

The subjects of the experiment were 12 Russian-speaking monolingual dyslexic children (mean age 9 years 9 months) living in Saint Petersburg and attending state schools. The inclusion criteria were extremely low indices of accuracy and fluency of reading, namely, $\geq 1.5 \mathrm{SD}$ (standard deviation) below the average for the target age group, according to the standardized reading test for Russian-speaking children (Kornev 2003, Kornev, Išimova 2010). Children with mental retardation and vision or hearing impairments were excluded from the experiment. The control group consisted of 12 Russian-speaking monolingual TD peers attending the same schools in Saint Petersburg.

\subsection{Visual stimuli}

Two picture sequences, the Baby Birds and the Baby Goats (Gagarina et al. 2012), were selected for eliciting the narratives. Each sequence consisted of six coloured pictures $(10 \times 10 \mathrm{~cm})$, without a text (see Appendix). In order to achieve comparability across narratives, the authors of the visual stimuli have aimed for congruence between the scripts and pictorial content by creating parallel storylines for the picture sequences. However, after a pilot study (Kornev, Balčiūnienè 2014), the Baby-Goats sequence is considered more complex to perceive because of the parallel development of two episodes and more numerous protagonists. 


\subsection{Procedure}

Subjects from both the experimental and control groups performed two tasks, i.e. story generation (so called story-telling) and story retelling; both of the tasks were followed by ten comprehension questions. Each child was tested individually; the 1st and the 2nd session were separated by a few minutes of free talk between the interviewer and the child. The order of tasks was counterbalanced with regard to story complexity and task mode. Namely, half of the sample started with story-telling, while the others started with retelling. Half of the sample performed story-telling according to the Baby Birds sequence and retold a story according to the Baby Goats sequence, while the others did the opposite, i.e. they told a story according to the Baby Birds sequence and performed retelling according to the Baby Goats sequence.

\subsection{Measures}

In our study, both the micro- and macrostructure of narratives were analysed, but in the current paper only the macrostructure, namely, story structure and episode completeness, will be discussed.

Story structure (also called 'story grammar' (Stein, Glenn 1979), 'narrative quality' (Fey et al. 2004), or 'plotline' (Duinmeijer et al. 2012), etc.) has been analysed in a great number of studies. It can be generally interpreted as a set of structural elements that are logically connected to each other by temporal/causal means and thus create a coherent story. A concept of story structure was initially suggested by Vladimir Propp (1968) based on Russian folktales, and later on it was modified by a number of researchers and applied as a valuable tool for analysing fictional stories. According to the methodology of story grammar, a good narrative begins with a setting, continues with an initiating event or some explicit problem, the protagonist's attempt to solve a problem, and the result of that attempt (McCabe, Bliss 2003). Table 1 presents the set of structural elements of both the Baby Birds and the Baby Goats sequences.

Table 1. Macrostructural framework (a set of structural elements) of the sequences

\begin{tabular}{|c|l|l|l|}
\hline \multirow{4}{*}{ Episode } & Element & \multicolumn{1}{|c|}{ Baby Birds } & \multicolumn{1}{c|}{ Baby Goats } \\
\cline { 2 - 4 } & Setting & One day... & Once upon a time... \\
\hline \multirow{4}{*}{1} & Goal & $\begin{array}{l}\text { The mother bird wants to feed her } \\
\text { chicks. }\end{array}$ & $\begin{array}{l}\text { The mother goat wants to help her baby } \\
\text { goat. }\end{array}$ \\
\cline { 2 - 4 } & Attempt & The mother bird flies away. & The goat runs into the water. \\
\cline { 2 - 4 } & Outcome & The mother bird brings a warm. & The goat saves the baby goat. \\
\hline \multirow{4}{*}{2} & Goal & The cat wants to catch the chicks. & The fox wants to catch the other baby goat. \\
\cline { 2 - 4 } & Attempt & The cat starts climbing the tree. & The fox grabs the baby goat. \\
\cline { 2 - 4 } & Outcome & The dog stops the cat. & The bird stops the fox. \\
\hline \multirow{4}{*}{3} & Goal & The dog wants to help the chicks. & The bird wants to help the baby goat. \\
\cline { 2 - 4 } & Attempt & The dog grabs the cat's tail. & The bird grabs the fox's tail. \\
\cline { 2 - 4 } & Outcome & The cat runs away. & The fox runs away. \\
\hline
\end{tabular}


During the experiment, each of the structural elements (i.e. setting, goal, attempt, and outcome of each episode) was scored 1 point, thus the story structure was scored $0-10$ points in total. The original scoring version was suggested by Gagarina et al. (2012), but later on it was modified by the authors of this paper (Kornev, Balčiūnienè 2014), in order to develop a more flexible and sensitive tool for scoring narrative structure.

Episode completeness is a relatively novel measure in narrative studies. In addition to the story structure (i.e. a purely quantitative characteristic), episode complexity/completeness (i.e. a qualitative characteristic) has been measured in a few studies (Coggins et al. 1998). Despite treating Goal, Attempt and Outcome as merely classical components of event structure, these elements have been evaluated from the perspective of the narrator's programming ability. Following the latter methodology, all episodes are classified into complete and incomplete ones. A complete episode consists of 1) an initiating event that prompts a character to act (Goal), 2) an Attempt related to the goal, and 3) a direct consequence (Outcome) of the attempt. A partial (incomplete) episode consists of one or two components (e.g., goal and attempt, or bare attempt). Unfortunately, just a few studies (Reilly et al. 1998, Grice, Wright-Harp 2004, Lê et al. 2011) have attempted to analyse the incomplete episodes, thus almost nothing is known about their structure and functions. It should be considered that separate episode completeness is based on some processes distinct from the whole story structure organisation. Episode completeness thus appears to be a useful macrostructural measure for narrative evaluation.

In our study, the episodes were classified into complete and incomplete ones and all of them were scored accordingly (see Table 2).

Table 2. Scoring episode completeness

\begin{tabular}{|c|l|l|c|}
\hline Episode & \multicolumn{1}{|c|}{ Structure } & \multicolumn{1}{c|}{ Example of an episode } & Points \\
\hline \multirow{5}{*}{ Complete } & $\begin{array}{l}\text { Goal-Attempt- } \\
\text { Outcome }\end{array}$ & $\begin{array}{l}\text { The mother bird wanted to feed her chicks. She flew } \\
\text { away and brought them a worm. }\end{array}$ & 4 \\
\hline \multirow{5}{*}{ Incomplete } & Goal-Attempt & $\begin{array}{l}\text { The mother bird wanted to feed her chicks, thus she } \\
\text { flewd away. }\end{array}$ & 3.5 \\
\cline { 2 - 4 } & Goal-Outcome & $\begin{array}{l}\text { The mother bird wanted to feed her chicks and bring } \\
\text { them a worm. }\end{array}$ & 3 \\
\cline { 2 - 4 } & Attempt-Outcome & $\begin{array}{l}\text { The mother bird flew away and brought a worm to her } \\
\text { chicks. }\end{array}$ & 2 \\
\cline { 2 - 4 } & Bare Goal & The mother bird wanted to feed her chicks. & 1.5 \\
\cline { 2 - 4 } & Bare Attempt & The mother bird flew away. & 1 \\
\cline { 2 - 4 } & Bare Outcome & The mother bird brought a worm to her chicks. & 1.5 \\
\hline
\end{tabular}

As can be seen, the most valuable (4 points) episodes were the complete ones, while bare Attempts were scored only 1 point. Since for both the Baby Birds and the Baby Goats sequences three episodes (the mother bird, the cat, and the dog; the mother goat, the fox, and the bird) were designed, the episode completeness was scored $\mathrm{O}-12$ points in total. 


\section{Results}

At the first step of analysis, the 1st session results were recognised as the basic level of achievements in narrative production. A one-way ANOVA ${ }^{1}$ (Mertler, Vannata 2002, Larsen, Marx 2011) analysis revealed the only distinction between the groups, in episode completeness $(\mathrm{F}=4.31 ; \mathrm{P}<0.05)$. A factorial $\mathrm{ANOVA}^{2}$ evidenced that the indices of story structure complexity and episode completeness were influenced in participants by different variables: structure complexity was influenced by the task mode $\left(\mathrm{F}=6.05 ; \mathrm{P}<0.026 ; \eta^{2}=0.274\right)$ while episode completeness was influenced by the group the participant belonged to $\left(F=5.45 ; \mathrm{P}<0.033 ; \eta^{2}=0.25\right)$. Namely, story-telling episode completeness was significantly worse in the dyslexic group than in the TD children $(\mathrm{F}=10.15 ; \mathrm{P}<0.01)$. Story-telling structure complexity was also less advanced in the dyslexics than in the TD group but the difference was not statistically significant $(\mathrm{F}=4.39 ; \mathrm{P}<0.06)$.

Turning to the particular non-linguistic factors, it should be noted that the task mode significantly influenced the story structure complexity as was mentioned above; the story structure complexity index was significantly higher in retelling than in telling ( $\mathrm{F}=5.57 ; \mathrm{P}<0.028)$. Episode completeness was significantly influenced by the task mode only in the Baby Goats story $\left(\mathrm{F}=8.02 ; \mathrm{P}<0.022 ; \eta^{2}=0.50\right)$. Both dyslexics and TD children had the highest score in this index. In story retelling, dyslexics did not differ from the TD children in any indices.

At the second step of analysis, the influence of the task order on narrative macrostructure was estimated. In this study, the main point of our interests was dynamic changes of narrative production quality influenced by recent experience. Hence, we attempted to evaluate the quality of a) story telling in the 2nd session preceded by a story retelling in the 1st session, and b) story retelling in the 2nd session preceded by a story telling in the 1st session. Our results confirmed the preliminary expectation that the execution of story retelling in the 1st session should influence the macrostructural features of story-telling in the 2nd session. Namely, story-telling structure and episode completeness were more advanced in the 2nd session than in the 1st one; however, this result was obtained within only the dyslexic group (see Figures 1a, 1b). Because of the small size of the groups, a significant difference was found only in the episode completeness indices ( $\mathrm{F}=4.08$; $\mathrm{P}<0.05$ ). This distinction was valid for only the Baby Birds story (see Figure 2a, 2b).

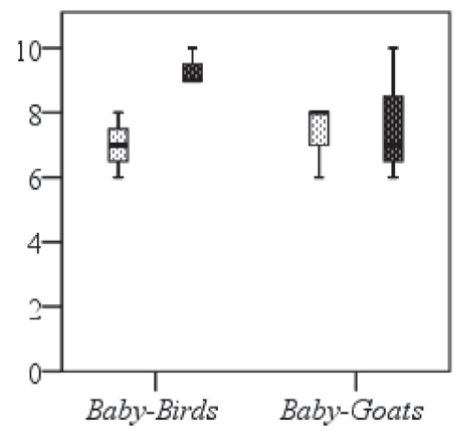

a) Story structure

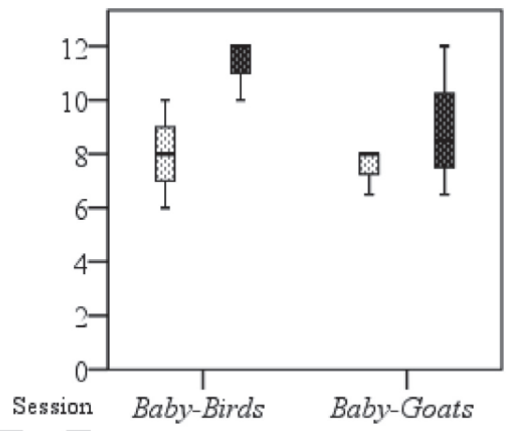

b) Episode completeness

Figure 1. Story structure and episode completeness in storytelling in dyslexics

1 The one-way analysis of variance (ANOVA) is used to determine whether there are any significant differences between the means of independent (unrelated) groups.

2 Factorial ANOVA or a general linear model is a general procedure for analysis of variance and covariance as well as regression. 


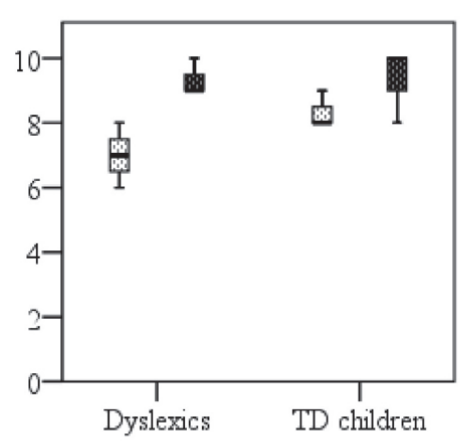

a) Story structure

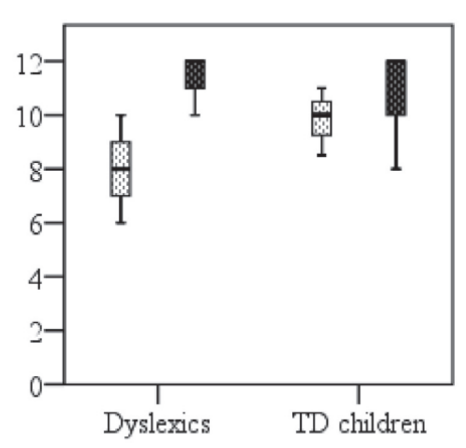

b) Episode completeness

Figure 2. Story structure and completeness in telling the Baby-Birds

As a novel approach in narrative assessment, a qualitative analysis of episode completeness was carried out, i.e. the distribution of structural types of episodes was estimated. The most prevalent episode structural types were the following: 'Goal-Attempt-Outcome', 'Goal-Outcome', 'Goal-Attempt', 'Attempt-Outcome', 'Bare goal', 'Bare Attempt' and 'Bare Outcome'. From the perspective of a dynamic approach, we attempted to evaluate the impact of the non-linguistic factors, i.e., 'session' (task order), 'story' (story complexity), and 'mode', on episode completeness. In order to achieve the most reliable results, story-telling and story retelling were analysed separately.

A factorial ANOVA analysis revealed that structure complexity was influenced by the variable 'story' and the interacting variables 'story' $\mathrm{x}$ 'session' (respectively, $\mathrm{F}=7.0 ; \mathrm{P}<0.018 ; \eta^{2}=0.30 ;$ and $\left.\mathrm{F}=5.14 ; \mathrm{P}<0.038 ; \eta^{2}=0.24\right)$; episode completeness was influenced by the interacting variables 'group' $\mathrm{x}$ 'session' $(\mathrm{F}=5.36$; $\mathrm{P}<0.034 ; \eta=0.251)$. In the Baby Goats story presented in the 1st session, the groups performed differently: the dominant episode structure pattern in TD children was ' $\mathrm{GAO}+\mathrm{G}+\mathrm{A}$ ' (the difference between the groups was significant; $\mathrm{F}=12.31$; $\mathrm{P}<0.006$ ), while the dyslexic children preferred the ' $\mathrm{GO}+\mathrm{AO}+\mathrm{O}$ ' structure (respectively, $\mathrm{F}=3.91 ; \mathrm{P}<0.076$ ) (see Figure 3). Moreover, in dyslexics, structurally incomplete episodes were prevalent both in telling and retelling.

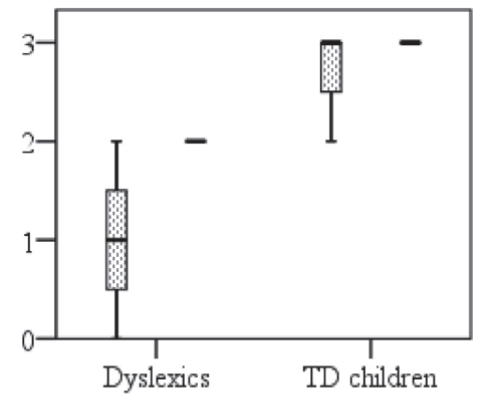

a) A number of patterns 'GAO+G+A'

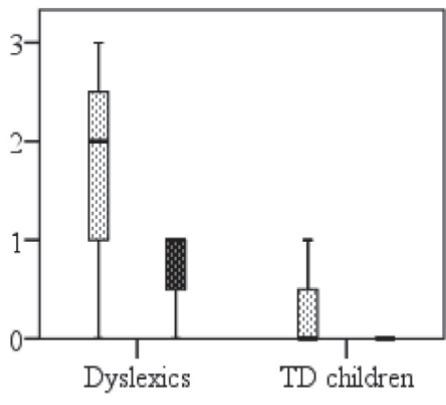

b) A number of patterns Story mode
belling ${ }^{\text {Retelling }}$ 'GO+AO+O'

Figure 3. Episode structure patterns in telling the Baby Goats

One more significant factor for story telling was session (the task order). In the TD children, complete episodes were more numerous in the 1st session (see Table 
4 and Figure 3), while the dyslexics demonstrated the reverse tendency (although the difference was not significant).

As for story retelling, the task order did not have any influence on episode completeness in either dyslexic or TD children (see Table 3).

Table 3. Macrostructural measures

\begin{tabular}{|c|c|c|c|c|c|c|c|}
\hline \multirow[b]{2}{*}{ Measure } & \multicolumn{2}{|c|}{$\begin{array}{l}\text { DY children } \\
\qquad N=12\end{array}$} & \multicolumn{2}{|c|}{$\begin{array}{c}\text { TD children } \\
\mathrm{N}=12\end{array}$} & \multirow[b]{2}{*}{ df } & \multirow[b]{2}{*}{$\mathrm{F}$} & \multirow[b]{2}{*}{ Sig. } \\
\hline & Mean & Std Dev & Mean & Std Dev & & & \\
\hline \multicolumn{8}{|c|}{ Telling } \\
\hline Story structure & 7.83 & 1.47 & 8.0 & 1.21 & 1 & 0.092 & 0.76 \\
\hline Episode completeness & 8.96 & 2.21 & 9.67 & 1.76 & 1 & 0.753 & 0.39 \\
\hline Internal state terms & 4.00 & 1.91 & 4.92 & 3.09 & 1 & 0.77 & 0.39 \\
\hline Comprehension questions & 8.42 & 1.08 & 9.33 & 1.15 & 1 & 4.02 & 0.06 \\
\hline \multicolumn{8}{|c|}{ Retelling } \\
\hline Story structure & 8.0 & 1.59 & 8.58 & 1.0 & 1 & 1.01 & 0.33 \\
\hline Episode completeness & 9.62 & 1.94 & 10.46 & 1.50 & 1 & 1.02 & 0.32 \\
\hline Internal state terms & 4.17 & 3.01 & 4.83 & 2.44 & 1 & 0.36 & 0.56 \\
\hline Comprehension questions & 9.00 & 0.85 & 8.75 & 1.36 & 1 & 0.29 & 0.59 \\
\hline
\end{tabular}

Table 4. Impact of non-linguistic factors on macrostructural measures in dyslexic and TD children's storytelling

\begin{tabular}{|l|c|c|c|c|c|c|}
\hline & \multicolumn{3}{|c|}{ Dyslexic children N=12 } & \multicolumn{3}{c|}{ TD children N=12 } \\
\hline Independent variable & $\mathrm{F}$ & Sig. & $\eta 2$ & $\mathrm{~F}$ & Sig. & $\eta 2$ \\
\hline \multicolumn{7}{|c|}{ Story Structure } \\
\hline Story & 0.76 & 0.41 & 0.087 & 14.29 & 0.005 & 0.641 \\
\hline Story x Session & 1.71 & 0.227 & 0.176 & 5.14 & 0.053 & 0.391 \\
\hline \multicolumn{7}{|c|}{ Episode completeness } \\
\hline Session & 5.07 & 0.054 & 0.388 & 0.85 & 0.384 & 0.096 \\
\hline
\end{tabular}

\section{Discussion and conclusions}

A multitude of studies in dyslexia have focused on different aspects of linguistic deficits (Nation, Snowling 2004, Casalis, Cole 2004, Hogan et al. 2005, Robertson, Joanisse 2010). Similarly, narrative limitations found in dyslexics have usually been recognized in the scope of narrative language weakness (Davenport et al. 1986, Westerveld et al. 2008). However, according to the resource deficit hypothesis, the core limitations in dyslexics are caused by non-linguistic factors, namely by a cognitive resource deficit (van der Schoot et al. 2000, Kibby et al. 2004). In some studies, theapplicability of the cognitive approach to narrative analysis has been confirmed (Mar 2004, Wright et al. 2011). The present study aimed at testing the dynamic model in application to dyslexia by the means of narrative assessment.

In the current paper, we focused mainly on macrostructural measures and their dependency on the experimental setting, task presentation mode, and personal new 
experience gained during the experiment. Although the results of our experiment generally coincide with the findings of previous studies in dyslexic narrative language (Plaza 2000, Westerveld et al. 2008), the linguistic deficit in our dyslexic group was not as dramatic as initially expected. In the first session when performing the relatively easy task, i.e. the Baby Birds story, the dyslexic children did not differ from the TD children in either telling or retelling. Significant differences between the groups were revealed only in the more complex task, i.e. the Baby Goats story; the episode completeness was much less advanced in the dyslexic children than in the TD peers. The dyslexics produced the same amount of structural elements as TD children but in each event description they tended to form structurally simpler and/ or incomplete schemes without Goal or Attempt elements. Again, in the 2nd session in the less complex story they did not differ from the TD peers.

The discussion of the results should be started by stating that limitations in narrative text production are presumed to be caused by several different underlying mechanisms. One of them is inefficiency in developing logical (temporal and causal) relationships between events. Another one is difficulties in structuring an episode description. The episode is the central unit in the majority of story grammar models (e.g., Stein, Glenn 1979, Thorndyke, Yakovitch 1980). Episode components are defined as statements bearing information about some characters' goal, their attempts to solve the problem, and the consequences of their attempts (Liles et al. 1989). The production and structuring of episode descriptions is thought to involve processes that are not exclusively linguistic (Coelho et al. 1994).

Theoretically, narrative text limitations in dyslexics might be recognized as a consequence of their low reasoning capacity. This may be one of the expected factors that influenced the observed poverty in episode structure completeness. However, the dynamic approach indicated that a short experience of story retelling in the 1st session provided a sufficient base for the dyslexic children to improve their story structure and episode completeness in the 2nd session. Consequently, the limitations in narrative structure should be treated rather as a procedural inefficiency related to a cognitive resource deficit (Coelho et al. 1994, Ferstl, Cramon 2001, Mar 2004). The influence of the 1st session task might be recognised as a priming effect (Snedeker, Thothathiri 2008, Eisenbeiss 2010). Execution of the retelling task in the 1st session probably activates a cerebral network that underlies the story production process and enables structural composition. This effect was extremely evident when the more complex picture sequence (i.e. the Baby Goats) was presented for retelling in the 1st session and followed by a telling of the less complex the Baby Birds story.

The other problem the dyslexics faced was the qualitative organization of episode structure. As was mentioned above, episodes are the basic elements of story grammar. Following van Dijk and Kintsch (1983), we recognize episodes as the macro-propositions that compose the plot. In our study, each of the episodes included 3 propositions, i.e. a goal, attempt, and outcome. Hence, when telling a story, children had to recognise each of the propositions, to relate them into a logical sequence, and to verbalise the sequence. The results of our study highlighted that children with dyslexia generally tended to produce more structurally incomplete episodes in comparison to their TD peers. Most often in dyslexics the Goal and the Attempt were omitted. The omission of the Goal should be related to the absence of 
direct pictorial signs for this structural component. The child has to derive the Goal from the whole sense of the event. The omission of the Attempt could be explained by the unstructured global event recognition of dyslexics. They covertly imply the Attempt in the description of the Outcome (e.g. The baby birds were saved and happy. The foxwas scared by the bird.). This tendency was extremely evident in the 1st session. In the inverse task order, i.e. story telling in the 2nd session preceded by story retelling in the 1st session and answering comprehension questions, episode completeness significantly increased and became equal to that of TD children (see Figure 2b). Taking into account this flexibility and the dynamic changes in episode structure, it should be reasonable to argue that this limitation was caused by procedural factors, not by a deficit in reasoning or language. Some previous studies have shown that the larger utterance units are explored in discourse planning, the more cognitive resources are required (Swets et al. 2014). Consequently, the cognitive resource deficit should result in simple and short phrases as well as structurally less complex narrative text.

These explanations do not exclude the fact of linguistic drawbacks in the dyslexic narrative production. In our previous paper (Kornev, Balčiūnienè 2014), we have argued for evidence of a semantic deficit in the denomination of the protagonists. Hence, our future studies in dyslexic children narratives will be focused not only on the macro- but also on the microstructural analysis.

In conclusion, it should be noted that our experience with the dynamic approach to narrative assessment lends support to its value as a research tool. The novel episode completeness analysis proved to be an effective and informative method that can highlight new mechanisms of narration and thus extend the classic narrative analysis by the addition of qualitative information.

$\begin{array}{ll}\text { Abbreviations } \\ \text { A } & \text { attempt } \\ \text { ADHD } & \text { attention deficit hyperactivity disorder } \\ \text { DY } & \text { dyslexic } \\ \text { G } & \text { goal } \\ \text { LI } & \text { language-impaired } \\ \text { O } & \text { outcome } \\ \text { TD } & \text { typically developing }\end{array}$

\section{References}

Bellani, Marcella; Moretti, Anna; Perlini, Cinzia; Brambilla, Paolo 2011. Language disturbances in ADHD. - Epidemiology and Psychiatric Sciences, 20 (4), 311-315. http:// dx.doi.org/10.1017/S2045796011000527

Bliss, Lynn S.; McCabe, Allyssa 2008. Personal narratives. Cultural differences and clinical implications. - Topics in Language Disorders, 28 (2), 162-177. http://dx.doi. org/10.1097/01.TLD.0000318936.31677.2d

Bliss, Lynn S.; McCabe, Allyssa; Miranda, Elisabeth A. 1998. Narrative assessment profile: Discourse analysis for school-age children. - Journal of Communication Disorders, 31 (4), 347-363. http://dx.doi.org/10.1016/So021-9924(98)oooo9-4

Botting, Nicola 2002. Narrative as a tool for the assessment of linguistic and pragmatic. - Child Language Teaching and Therapy, 18 (1), 1-21. http://dx.doi. org/10.1191/0265659002ct2240a 
Cain, Kate 2003. Text comprehension and its relation to coherence and cohesion in children's fictional narratives. - British Journal of Developmental Psychology, 21 (3), 335-351. http://dx.doi.org/10.1348/026151003322277739

Casalis, Severine; Pascale, Cole 2004. Morphological awareness in developmental dyslexia. Annals of Dyslexia, 54 (1), 114-138. http://dx.doi.org/10.1007/s11881-004-0006-z

Coelho, Carl A. 2002. Story narratives of adults with closed head injury and non-brain-injured adults: Influence of socioeconomic status, elicitation task, and executive functioning. Journal of Speech, Language, and Hearing Research, 45 (December), 1232-1248. http://dx.doi.org/10.1044/1092-4388(2002/099)

Coelho, Carl A.; Liles, Betty Z.; Duffy, Robert 1994. Cognitive framework: A description of discourse abilities in traumatically brain-injured adults. - Ronald L. Bloom, Loraine K. Obler, Susan De Santi, Jonathan S. Ehrlich (Eds.). Discourse Analysis and Applications: Studies in Adult Clinical Populations. Hillsdale, NJ: Erlbaum, 96-110.

Coggins, Truman E.; Friet, T.; Morgan, T. 1998. Analysing narrative productions in older school-age children and adolescents with fetal alcohol syndrome: An experimental tool for clinical applications. - Clinical Linguistics \& Phonetics, 12 (3), 221-236. http:// dx.doi.org/10.3109/02699209808985223

Davenport, Linda; Yingling, Charles D.; Fein, George; Galin, David; Johnstone, Jack; Porter, Langley 1986. Narrative speech deficits in dyslexics. - Journal of Clinical and Experimental Neuropsychology, 8 (4), 347-361. http://dx.doi. org/10.1080/01688638608401326

Dijk, Teun A. van; Kintsch, Walter 1983. Strategies of Discourse Comprehension. NY: New York Academic Press.

Duinmeijer, Iris; de Jong, Jan; Scheper, Annette 2012. Narrative abilities, memory and attention in children with a specific language impairment. - International Journal of Language \& Communication Disorders, 47 (5), 542-555. http://dx.doi. org/10.1111/j.1460-6984.2012.00164.x

Eisenbeiss, Sonja 2010. Production methods in language acquisition research. - Elma Blom, Sharon Unsworth (Eds.). Experimental Methods in Language Acquisition Research. Amsterdam: John Benjamins Publishing, 11-34.

Ferstl, Evelyn C.; von Cramon, D. Yves 2001. The role of coherence and cohesion in text comprehension: An event-related fMRI study. - Cognitive Brain Research, 11 (3), 325-340. http://dx.doi.org/10.1016/Sog26-6410(01)00007-6

Fey, Marc E.; Catts, Hugh W.; Proctor-Williams, Kerry; Tomblin, J. Bruce; Zhang, Xuyang 2004. Oral and written story composition skills of children with language impairment. - Journal of Speech, Language, and Hearing Research, 47 (December), 1301-1318. http://dx.doi.org/10.1044/1092-4388(2004/098)

Gagarina, Natalia; Klop, Daleen; Kunnari, Sari; Tantele, Koula; Välimaa, Taina; Balčiūnienė, Ingrida; Bohnacker, Ute; Walters, Joel 2012. MAIN: Multilingual Assessment Instrument for Narratives. ZAS Papers in Linguistics 56. Berlin: ZAS.

Gillam, Ronald B.; Pearson, Nils A. 2004. Test of Narrative Language. Austin, TX: Pro-Ed.

Gillam, Ronald B.; Peña, Elisabeth D.; Miller, Lynda 1999. Dynamic assessment of narrative and expository discourse. - Topics in Language Disorders, 20 (1), 33-47. http://dx.doi. org/10.1097/00011363-199911000-00005

Gorin, Joanna; Embretson, Susan E. 2006. Item difficulty modeling of paragraph comprehension items. - Applied Psychological Measurement, 30 (5), 394-411. http://dx.doi. org/10.1177/0146621606288554

Grice, Angela M.; Wright-Harp, Wilhelmina 2004. The narrative performance of adolescents and emerging adults. - Paper presented at the NIDCD Research Symposium in Aphasiology. Park City, UT.

Hickmann, Maya 2003. Children's Discourse: Person, Space and Time Across Languages. Cambridge: Cambridge University Press. 
Hogan, Tiffany P.; Catts, Hugh W.; Little, Todd D. 2005. The relationship between phonological awareness and reading: Implications for the assessment of phonological awareness. - Language, Speech, and Hearing Services in Schools, 36 (4), 285-293. http://dx.doi.org/10.1044/0161-1461(2005/029)

Im-Bolter, Nancie; Johnson, Janice; Pascual-Leone, Juan 2006. Processing limitations in children with specific language impairment: The role of executive function. - Child Development, 77 (6), 1822-1841. http://dx.doi.org/10.1111/j.1467-8624.2006.00976.x

Kibby, Michelle Y.; Kroese, Judith M.; Morgan, Allison E.; Hiemenz, Jennifer R.; Cohen, Moris J.; Hynd, George W. 2004. The relationship between perisylvian morphology and verbal short-term memory functioning in children with neurodevelopmental disorders. - Brain and Language, 89 (1), 122-135. http://dx.doi.org/10.1016/ S0093-934X(03)00310-9

Kintsch, Walter 1988. The role of knowledge in discourse comprehension construction-integration model. - Psychological Review, 95 (2), 163-182. http://dx.doi. org/10.1037/0033-295X.95.2.163

Kintsch, Walter 1998. Comprehension: A Paradigm for Cognition. NY: Cambridge University Press.

Kintsch, Walter; Dijk, Teun A. van 1978. Toward a model of text comprehension and production. - Psychological Review, 85 (5), 363-394. http://dx.doi.org/ 10.1037/0033-295X.85.5.363

Kornev, Aleksandr N. 1995. Disleksija i disgrafija u detej. Sankt-Peterburg: Gippokrat.

Kornev, Aleksandr N. 2003. Narušenija čtenija i pis'ma. Sankt-Peterburg: Reč'.

Kornev, Aleksandr N. 2006. Sistemnyj analiz psihologičeskogo razvitija detej s nedorazvitiem reči. Avtoreferat dissertacii na soiskanie učenoj stepeni doktora psihologičeskih nauk. Sankt-Peterburg: Psihonevrologičeskij institut im. B. M. Behtereva.

Kornev, Aleksandr N.; Balčiūnienè, Ingrida 2014. Story (re-)telling and reading in children with dyslexia: Language or cognitive resource deficit? - Book of Abstracts: LSCD2014. London: UCL, 23-26.

Kornev, Aleksandr N.; Išimova, Olga A. 2010. Metodika diagnostiki disleksii u detej. Metodičeskoe posobie. Sankt-Peterburg: Izdatel'stvo Politehničeskogo universiteta.

Kornev, Aleksandr N.; Rakhlin, Natalia; Grigorenko, Elena L. 2010. Dyslexia from a crosslinguistic and cross-cultural perspective: The case of Russian and Russia. - Learning Disabilities: A Contemporary Journal, 8 (1), 51-78.

Larsen, Richard J.; Marx, Morris L. 2011. Introduction to Mathematical Statistics and Its Applications. 5th edition. Prentice Hall.

Lê, Karen; Coelho, Carl A.; Mozeiko, Jennifer; Grafman, Jordan 2011. Measuring goodness of story narratives. - Journal of Speech, Language, and Hearing Research, 54 (February), 118-126. http://dx.doi.org/10.1044/1092-4388(2010/09-0022)

Leontyev, Aleksej A. 1997. Osnovy psiholingvistiki. Moskva: Smysl.

Leontyev, Aleksej A. 2004. Jazyk i rečevaja dejatel'nost' v obščej i pedagogičeskoj psihologii. Moskva: Izdatel'stvo Moskovskogo psihologo-social'nogo instituta.

Liles, Betty Z.; Coelho, Carl A.; Duffy, Robert; Zalagens, Mary Rigdon 1989. Effects of elicitation procedures on the narratives of normal and closed head-injured adults. - Journal of Speech and Hearing Disorders, 54 (August), 356-365. http://dx.doi.org/10.1044/ jshd. 5403.356

Lindgren, Scott D.; de Renzi, Ennio; Richman, Lynn C. 1985. Cross-national comparisons of developmental dyslexia in Italy and the United States. - Child Development, 56 (6), 1404-1417. http://dx.doi.org/10.2307/1130460

Lyon, G. Reid; Shaywitz, Sally E.; Shaywitz, Bennet A. 2003. Defining dyslexia, comorbidity, teachers' knowledge of language and reading. - Annals of Dyslexia, 53 (1), 1-14. http://dx.doi.org/10.1007/s11881-003-0001-9 
MacWhinney, Brian; Bates, Elisabeth 1989. Functionalism and the competition model. B. MacWhinney, E. Bates (Eds.). The Crosslinguistic Study of Sentence Processing. New York: Cambridge University Press, 3-73.

Mar, Raymond A. 2004. The neuropsychology of narrative: Story comprehension, story production and their interrelation. - Neuropsychologia, 42 (10), 1414-1434. http:// dx.doi.org/10.1016/j.neuropsychologia.2003.12.016

Marton, Klara 2008. Visuo-spatial processing and executive functions in children with specific language impairment. - International Journal of Language \& Communication Disorders, 43 (2), 181-200. http://dx.doi.org/10.1080/16066350701340719

Mayer, Mercer 1967. A Boy, a Dog and a Frog. New York: Penguin.

McAndrew, Edel 1999. The relationship between self-esteem and language disordered children. - Child Language Teaching and Therapy, 15 (3), 219-232. http://dx.doi. org/10.1191/026565999666834880

McCabe, Allyssa; Bliss, Lynn S. 2003. Patterns of Narrative Discourse: A Multicultural, Life Span Approach. Boston, MA: Allyn and Bacon.

Mertler, Craig A.; Vannata, Rachel A. 2002. Advanced and Multivariate Statistical Methods. Practical Application and Interpretation. 2nd edition. McNaughton and Gunn, Inc.

Nation, Katie; Snowling, Margaret J. 2004. Beyond phonological skills: Broader language skills contribute to the development of reading. - Journal of Research in Reading, 27 (4), 342-356. http://dx.doi.org/10.1111/j.1467-9817.2004.00238.x

Perfetti, Charles A. 1994. Psycholinguistics and reading ability. - Morton A. Gernsbacher (Ed.). Handbook of Psycholinguistics. San Diego, CA: Academic Press, 849-894.

Peterson, Carole; Dodsworth, Pamela 1991. A longitudinal analysis of young chindren's cohesion and noun specification in narratives. - Journal of Child Language, 18 (2), 397-415. http://dx.doi.org/10.1017/S0305000900011120

Plaza, Monicue 2000. Reference and evaluation in narrative speech of a group of Frenchspeaking children. - Psycholinguistics on the Threshold of the Year 2000: Proceedings of the 5th International Congress of the International Society of Applied Psycholinguistics, 665-668.

Pressley, Michael 2006. Children who experience problems in learning to read. - M. Pressley (Ed.). Reading Instruction That Works. Third Edition: The Case for Balanced Teaching. The Guilford Press, 66-95.

Propp, Vladimir 1968. Morphology of the Folktale. Austin, TX: University of Texas Press.

Reilly, Judy S.; Bates, Elizabeth A.; Marchman, Virginia A. 1998. Narrative discourse in children with early focal brain injury. - Brain and Language, 61 (3), 335-375. http:// dx.doi.org/10.1006/brln.1997.1882

Renfrew, Catherine E. 1969. The Bus Story: A Test of Continuous Speech. North Place, Old Headington: Oxford.

Robertson, Erin K.; Joanisse, Marc F. 2010. Spoken sentence comprehension in children with dyslexia and language impairment: The roles of syntax and working memory. - Applied Psycholinguistics, 31 (1), 141-165. http://dx.doi.org/10.1017/S0142716409990208

Schneider, Phyllis 1996. Effects of pictures versus orally presented stories on story retellings by children with language impairment. - American Journal of Speech-Language Pathology, 5 (February), 86-96. http://dx.doi.org/10.1044/1058-0360.0501.86

Schneider, Phyllis; Dubé, Rita V. 2005. - American Journal of Speech-Language Pathology, 14 (February), 52-6o. http://dx.doi.org/10.1044/1058-0360(2005/007)

Schneider, Phyllis; Dubé, Rita V.; Hayward, Denyse V. 2005. The Edmonton Narrative Norms Instrument. Retrieved from University of Alberta Faculty of Rehabilitation Medicine website: http://www.rehabresearch.ualberta.ca/enni (27.2.2015).

Shaywitz, Sally E.; Shaywitz, Bennett A. 2003. Dyslexia (specific reading disability). - Pediatrics in Review, 24 (5), 147-153. 
Smiley, Sandra S.; Oakley, Drew D.; Worthen, David; Campione, Joseph C.; Brown Ann L. 1977. Recall of thematically relevant material by adolescent good and poor readers as a function of written versus oral presentation. - Journal of Education Psychology, 69 (4), 381-387. http://dx.doi.org/10.1037/0022-0663.69.4.381

Snedeker, Jesse; Thothathiri, Malathi 2008. What lurks beneath: Syntactic priming during language comprehension in preschoolers (and adults). - Irina A. Sekerina, Eva M. Fernández, Harald Clahsen (Eds.). Developmental Psycholinguistics: On-line methods in Children's Language Processing. Language Acquisition and Language Disorders 44. Amsterdam: John Benjamins Publishing Company, 137-168. http:// dx.doi.org/10.1075/lald.44

Snowling, Margaret J. 1996. Dyslexia: A hundred years on. - BMJ, 313 (2), 1096-1097. http:// dx.doi.org/10.1136/bmj.313.7065.1096

Soodla, Piret 2011. Picture-Elicited Narratives of Estonian Children at the KindergartenSchool Transition as a Measure of Language Competence. Tartu: Tartu Ülikooli Kirjastus. http://hdl.handle.net/10062/16715

Soodla, Piret; Kikas, Eve; Pajusalu, Renate; Adamka, Aive; Parm, Sirli 2010. Vahendamata ja vahendatud narratiiv laste kõnearengu hindamisel. [Self-generated and retold narratives as a tool of language assessment.] - Eesti Rakenduslingvistika Ühingu aastaraamat, 6, 277-296. http://dx.doi.org/10.5128/ERYa6.17

Stein, Nancy L.; Glenn, Christine G. 1979. An analysis of story comprehension in elementary school children. - R. Freedle (Ed.). Discourse Processing: Multidisciplinary Perspectives. Norwood, NJ: Ablex.

Swets, Benjamin; Jacovina, Matthew E.; Gerrig, Richard J. 2014. Individual differences in the scope of speech planning: Evidence from eye-movements. - Language and Cognition, 6 (1), 12-44. http://dx.doi.org/10.1017/langcog.2013.5

Thorndyke, Perry W.; Yakovitch, Frank R. 1980. A critique of schema-based theories of human story memory. - Poetics, 9 (1-3), 23-49. http://dx.doi. org/10.1016/0304-422X(80)90011-X

Tucker, Frances M.; Hanlon, Robert E. 1998. Effects of mild traumatic brain injury on narrative discourse production. - Brain Injury, 12 (9), 783-792. http://dx.doi. org/10.1080/026990598122179

Schoot, Menno van der; Licht, Robert; Horsley, Tako M.; Sergeant, Joseph A. 200o. Inhibitory deficits in reading disability depend on subtype: Guessers but not spellers. - Child Neuropsychology, 6 (4), 297-312. http://dx.doi.org/10.1076/chin.6.4.297.3139

Veneziano, Edy; Hudelot, Christian 2009. Explaining events in narratives: The impact of scaffolding in 4 to 12 year old children. - Psychology of Language and Communication, 13 (1), 3-20. http://dx.doi.org/10.2478/v10057-009-0001-X

Voeller, Kytja K. S. 2004. Dyslexia. - Journal of Child Neurology, 19 (10), 740-744.

Westerveld, Marleen F.; Gillon, Gail T.; Moran, Catherine 2008. A longitudinal investigation of oral narrative skills in children with mixed reading disability. - International Journal of Speech-Language Pathology, 10 (3), 132-145. http://dx.doi. org/10.1080/14417040701422390

Wright, Heather H.; Capilouto, Gilson J.; Srinivasan, Cidambi; Fergadiotis, Gerasimos 2011. Story processing ability in cognitively healthy younger and older adults. Journal of Speech, Language, and Hearing Research, 54 (3), 900-917. http://dx.doi. org/10.1044/1092-4388(2010/09-0253) 
Appendix.

Stimulus material for the study (based on Gagarina et al. 2012)

The Baby Birds sequence
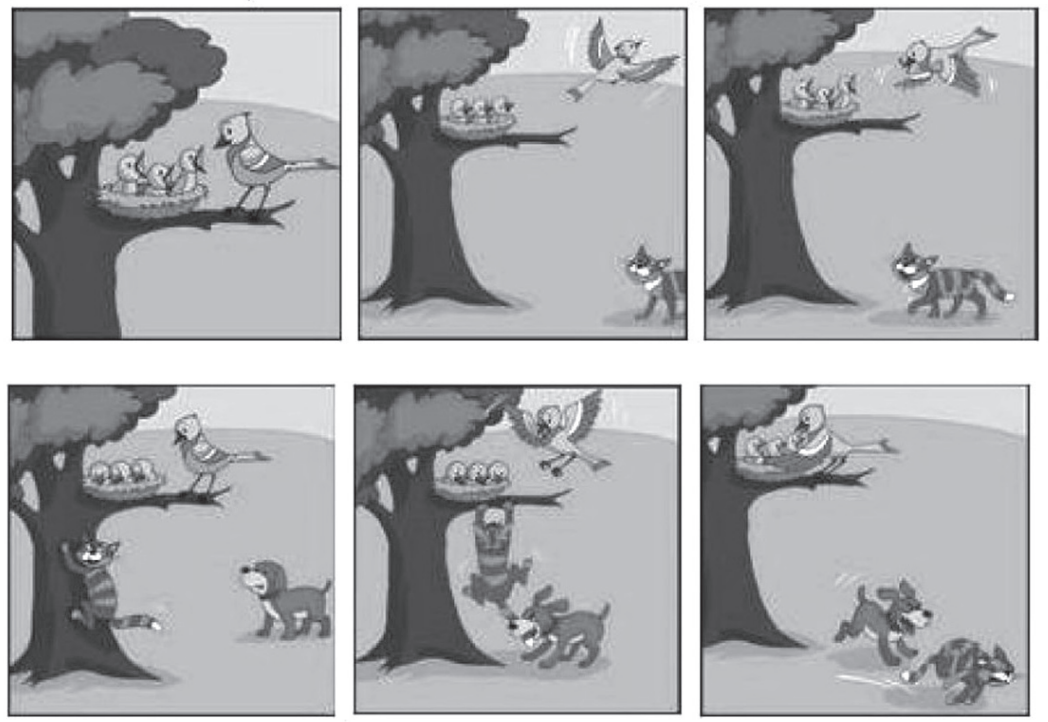

The Baby Goats sequence
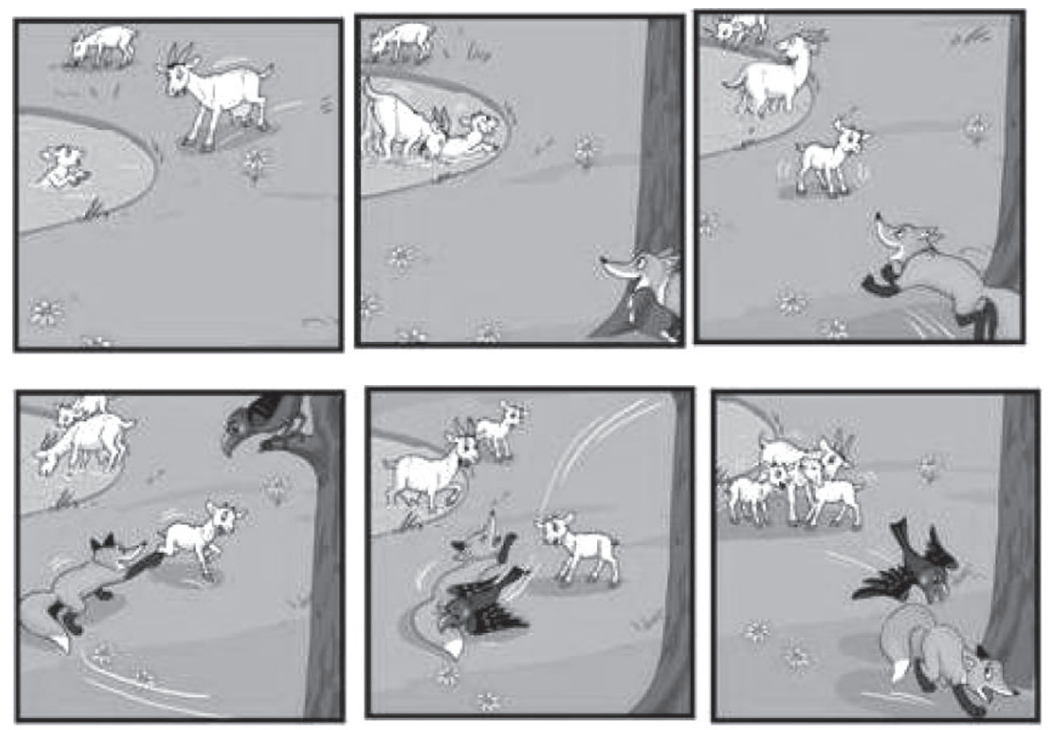

Ingrida Balčiūnienė (Vytautas Magnus University). Her research interests include first language acquisition, narrative analysis, and discourse analysis.

K. Donelaičio 58, 44248 Kaunas, Lithuania

i.balciuniene@hmf.vdu.It

Aleksandr N. Kornev (Saint-Petersburg State Pediatric Medical University). His research interests include child clinical psychology, speech/language pathology, and dyslexia.

Litovskaya 2, 194100, Saint Petersburg, Russia

k1949@yandex.ru 


\section{NARRATIVILOOME NÕRKUS \\ VENE DÜSLEKTIKUTEL: KEELELINE \\ VÕ̃I PROTSEDUURILINE PIIRATUS?}

\section{Aleksandr N. Kornev', Ingrida Balčiūniené ${ }^{2}$}

Peterburi Riiklik Pediaatriameditsiini Ülikool ${ }^{1}$, Vytautas Magnuse Ülikool $^{2}$

Uuring käsitleb keeleväliste tegurite mõju venekeelsete düslektiliste laste narratiiviloomele. Katserühm koosnes 12 düsleksiaga lapsest vanuses 9-10 aastat, kontrollrühmas oli 12 samaealist arenguhäireta last. Valim oli tasakaalustatud narratiivi laadi, jutustuse komplekssuse ja ülesannete järjekorra aspektist. Laiendasime klassikalist narratiivianalüüsi uudse dünaamilise lähenemisega, mis võimaldas hinnata narratiiviloome protseduurilisi karakteristikuid.

Uurimistulemused tõid välja kaks düslektikute narratiivikeele piiratuse põhjust: raskused inimeste ja sündmuste vaheliste loogiliste (ajaliste, põhjuslike) seoste kujundamises ja jutustuse episoodistruktuuri organiseerimises. Episoodistruktuuri suur paindlikkus ja dünaamilised muutused selles annavad põhjust järeldada, et düslektikute narratiivide keele piiratust tingivad pigem protseduurilised kui keelelised tegurid. Siiski leidub ka puhtkeelelisi vajakajäämisi.

Dünaamiline lähenemine narratiivi hindamisele on meie kogemuse põhjal vajalik uurimisviis. Episoodide täielikkuse dünaamiline käsitlus näitas end meie uurimuses tõhusa ja informatiivse meetodina, mis võib esile tuua uusi jutustamise mehhanisme ja seega avardada klassikalist narratiivianalüüsi kvalitatiivse informatsiooni abil.

Võtmesõnad: esimese keele omandamine, narratiivianalüüs, keele patoloogia, düsleksia, vene keel 